\title{
Epidemiological surveillance of leishmaniasis in the European Union: operational and research challenges
}

L Gradoni (luigi.gradoni@iss.it) ${ }^{1}$

1. Unit of Vector-borne Diseases and International Health, MIPI Department, Istituto Superiore di Sanità, Rome, Italy

Citation style for this article:

Gradoni L. Epidemiological surveillance of leishmaniasis in the European Union: operational and research challenges. Euro Surveill. 2013;18(30):pii=20539.

Available online: http://www.eurosurveillance.org/ViewArticle.aspx?Articleld=20539

Leishmaniasis is complex of vector-borne diseases caused by protozoan parasites of the genus Leishmania transmitted by the bite of phlebotomine sandflies. A dozen nosogeographical entities - characterised by different parasite, vector and reservoir host species, geographical distribution and clinical features in humans - affect 101 countries in tropical, subtropical and temperate zones of the world $[1,2]$. More than $90 \%$ of 200,000-400,000 global cases of visceral leishmaniasis (VL), the most severe form, are estimated to occur annually in India, Bangladesh, Sudan, South Sudan, Ethiopia and Brazil. A less severe form, cutaneous leishmaniasis (CL), is more widely distributed, accounting for 0.7-1.2 million cases each year in countries of Latin America, Mediterranean basin, Middle East and Central Asia.

Even though many physicians and public health experts still consider leishmaniasis a tropical disease, two entities associated with several Phlebotomus species are endemic in southern Europe: (i) zoonotic VL and $C L$ caused by $L$. infantum throughout the region, having dogs as reservoir host; and (ii) anthroponotic $C L$ caused by $L$. tropica, which occurs sporadically in Greece. More recently, a third parasite species (L. donovani, assumed to be anthroponotic) has been recorded in Cyprus, where it causes both VL and CL [3].

VL is endemic in nine countries of the European Union (EU). The World Health Organization's Department for the Control of Neglected Tropical Diseases has estimated a total VL incidence of approximately 410-620 cases each year during 2003 to 2008 in these endemic countries, adjusted to take into account a 'mild' 1.21.8-fold under-reporting [2]. Recent experiences from six of the nine countries - Bulgaria, Greece, Croatia, Italy, France and Spain - are presented in this special issue.

Zoonotic CL usually occurs in the same areas endemic for $\mathrm{VL}$, but there are probably many more cases than those registered (2.8-4.6-fold under-reporting has been estimated for the EU region [2]). As pointed out by Lachaud et al. for France [4], but also applicable to other EU countries endemic for $\mathrm{CL}$, cutaneous lesions due to $L$. infantum are often benign and patients are seen by general practitioners or dermatologists who generally do not report these cases or notify them even when mandatory.

Despite provoking a limited number of overt clinical cases - in comparison with global leishmaniasis figures - L. infantum represents a latent public health threat in the EU because studies performed in several endemic foci have disclosed a high prevalence of asymptomatic parasite carriers [5]. A recent example is provided for Croatia by Šiško-Kraljević et al. [6]. Hence, immunosuppressive conditions, either due to co-morbidities (e.g. human immunodeficiency virus (HIV) infection) or therapies (e.g. organ transplantation or treatment of immunological disorders [7]) may result in the reactivation of latent infections. In this regard, it should be emphasised that dermotropic L. infantum genotypes - the usual agents of benign $C L$ - may disseminate to cause severe $\mathrm{VL}$ in immunosuppressed individuals [8]. Such elevated prevalence of human infections could have been predicted from two strands of evidence: humans are frequently bitten by sandflies and $L$. infantum infections are widespread in dogs, a highly susceptible host [9]. In large parts of countries of southern EU, canine seroprevalence rates are estimated to be in the range of $5-30 \%$, which means that infection rates may reach values of $40-80 \%$ [10].

Some European countries at the north of regions with natural transmission of leishmaniasis have reported large series of VL and CL imported cases, many of which have acquired the parasitic infection during holidays in southern Europe [11-14]. In several instances, a definitive diagnosis of VL proved difficult and for one case, the period before symptom onset and specific treatment was longer than a year. Delay in diagnosis or misdiagnosis can also occur in southern European countries endemic for $\mathrm{VL}$, but in parts where cases occur rarely, as has been reported from a northern Italian region [15]. These observations suggest that awareness about leishmaniasis endemicity in Europe should be greatly increased among general practitioners and clinicians. 
Operational and research challenges concerning epidemiological surveillance of leishmaniasis in the European Union

Topic

Transnational information

Disease vs infection

Parasite identification

Domestic vs wild reservoir hosts

Phlebotomine vectors

Control measures
Challenges

Notification of leishmaniasis is not compulsory everywhere in Europe. Some endemic countries have national notification systems centralised at the Ministry of Health; others have compulsory or voluntary surveillance systems in endemic regions but not in nonendemic ones. Non-endemic countries of northern Europe rely on single (or a network of) reference centres that collect information on a voluntary basis.

There is limited harmonisation of the existing notification systems as regards case definition, clinical presentation and patient information.

In countries with compulsory notifiable systems, under-reporting of visceral leishmaniasis is estimated to be 1.2-1.8-fold, that of cutaneous leishmaniasis $2.8-4.6$-fold [2].

Travellers to endemic countries are not provided with adequate information on leishmaniasis risk and physicians often do not include leishmaniasis in differential diagnosis of travel-related diseases.

There is a lack of feedback from non-endemic countries registering leishmaniasis cases in travellers to the endemic countries visited by patients, which can hamper early identification of new or re-emerging foci.

Increasingly, there is evidence that clinical cases of leishmaniasis represent the tip of an 'infection iceberg', whose size (i.e. prevalence) is unknown in most of the endemic countries

Determinants for human clinical susceptibility are largely unknown, apart from some co-morbidities (e.g. human immunodeficiency virus (HIV) infection) or immunocompromising conditions, i.e. through immunosuppressive therapies.

Multilocus enzyme electrophoresis (MLEE), the gold standard for Leishmania identification, is available at reference centres of three European countries (France, Italy and Spain) [1]; however, there is risk that MLEE typing activities will be ended soon because they are expensive and laborious.

Different levels of accuracy may be required (e.g. species level at clinical centres, genotype level for epidemiological investigations); however, common protocols for molecular Leishmania identification are not available yet.

Updated geographical distribution of canine leishmaniasis, representing the most efficient sentinel for leishmaniasis transmission in a territory, is not available for all endemic countries

The epidemiological role of domestic hosts other than dogs (e.g. cats) is still unclear

The potential role of wild mammals (rodents, lagomorphs, carnivores) as reservoir hosts of Leishmania requires investigation because it can change with man-made environmental changes such as witnessed by the recent outbreak in Madrid, Spain [21].

Taxonomy and biology investigations on European phlebotomine species rely on a limited group of experts. Updated information on vector distribution is therefore lacking in some endemic countries and in neighbouring non-endemic ones.

Competence of permissive sandfly species needs to be elucidated as regards potential transmission of exotic Leishmania species imported into Europe.

The vectorial role of continental European species of sandflies (e.g. Phlebotomus mascitti) is still to be ascertained.

The primary control measure is avoiding deaths from the most severe form of leishmaniasis (visceral). General public and health professional awareness of the disease (both leading to early diagnosis) and appropriate therapy should be the mainstay for both endemic and non-endemic countries.

Vaccination combined with topical insecticides with sandfly anti-feeding properties should be recommended for dogs living in endemic areas or temporarily travelling from nonendemic to endemic areas. 
As an endemic country comprises known areas or foci of endemicity, it is interestingly to note that in some instances, travellers became infected after visiting an area that was not considered as endemic by the health authorities of the country visited [16]. This should encourage the development of systems for appropriate transnational information following leishmaniasis diagnosis in travellers.

Deaths due to VL, although possible, are rare. The disease has a slow chronic course, so that fatal cases may be patients with individual risk factors such as severe co-morbidities or, in case of young children, malnutrition associated with late diagnosis. On the other hand, deaths due to inappropriate use of VL drugs can be even more frequent. In some European countries, antimonial drugs are still in use for some categories of patients because of the high cost of liposomal amphotericin B [17] and it is well known that overdose of pentavalent antimony in adults can cause severe cardiac failures in addition to pancreatitis.

This special issue of Eurosurveillance, published in two parts, is a useful instrument to review diverse aspects of leishmaniasis in Europe related to topics such as the information and surveillance systems in place in countries within the EU, the current epidemiological situation and novel aspects related to parasite identification $[18,19]$, domestic and wild reservoir hosts [20] and vectors [9]. The main challenges associated with these topics are summarised in the Table.

In conclusion, leishmaniasis, a neglected disease, is rare in some countries of Europe, but endemic in others, having a great impact on individuals and the potential to spread further. The disease should be monitored carefully and systems for its notification should be harmonised at both national and transnational levels.

References

1. World Health Organization (WHO). Control of the leishmaniases: report of a meeting of the WHO Expert Committee on the Control of Leishmaniases, Geneva, 22-26 March 2010. Geneva: WHO; 2010. WHO technical report series; no. 949. Available from: http://whqlibdoc.who.int/trs/WHO_ TRS_949_eng.pdf

2. Alvar J, Vélez ID, Bern C, Herrero M, Desjeux P, Cano J, et al. Leishmaniasis worldwide and global estimates of its incidence. PLoS ONE 2012;7(5):e35671. http://dx.doi.org/10.1371/journal. pone.0035671 PMid:22693548 PMCid:PMC3365071

3. Antoniou M, Haralambous C, Mazeris A, Pratlong F, Dedet JP, Soteriadou K. Leishmania donovani leishmaniasis in Cyprus. Lancet Infect Dis. 2008;8(1):6-7. http://dx.doi.org/10.1016/ S1473-3099(07)70297-9

4. Lachaud L, Dedet JP, Marty P, Faraut F, Buffet P, Gangneux JP, et al. Surveillance of leishmaniases in France, 1999 to 2012. Euro Surveill. 2013;18(29): pii=20534. Available from: http://www. eurosurveillance.org/ViewArticle.aspx?Articleld =20534

5. Michel G, Pomares C, Ferrua B, Marty P. Importance of worldwide asymptomatic carriers of Leishmania infantum ( $L$. chagasi) in human. Acta Trop. 2011;119(2-3):69-75. http:// dx.doi.org/10.1016/j.actatropica.2011.05.012 PMid:21679680

6. Šiško-Kraljević K, Jerončić A, Mohar B, Punda-Polić V. Asymptomatic Leishmania infantum infections in humans living in endemic and non-endemic areas of Croatia, 2007 to 2009. Euro Surveill. 2013;18(29):pii=20533. Available from: http:// www.eurosurveillance.org/ViewArticle.aspx?Articleld $=20533$
7. Zanger P, Gabrysch S. Leishmaniasis in the era of tumor necrosis factor alpha antagonist therapy - a research agenda for Europe. Euro Surveill. 2013;18(30):pii=20542. Available from: http://www.eurosurveillance.org/ViewArticle. aspx?Articleld $=20542$

8. Gradoni L, Gramiccia M. Leishmania infantum tropism: strain genotype or host immune status? Parasitol Today. 1994;10(7):264-7. http://dx.doi. org/10.1016/0169-4758(94)90142-2

9. Antoniou M, Gramiccia M, Molina R, Dvorak V, Volf P. The role of indigenous phlebotomine sandflies and mammals in the spreading of leishmaniasis agents in the Mediterranean region. Euro Surveill. 2013;18(30):pii=20540. Available from: http:// www.eurosurveillance.org/ViewArticle.aspx?Articleld $=20540$

10. Franco AO, Davies CR, Mylne A, Dedet JP, Gállego M, Ballart $C$, et al. Predicting the distribution of canine leishmaniasis in western Europe based on environmental variables. Parasitology. 2011;138:1878-91. http://dx.doi.org/10.1017/ So03118201100148X PMid:21914251

11. Wall EC, Watson J, Armstrong M, Chiodini PL, Lockwood DN. Epidemiology of imported cutaneous leishmaniasis at the Hospital for Tropical Diseases, London, United Kingdom: use of polymerase chain reaction to identify the species. Am J Trop Med Hyg. 2012;86(1):115-8. http://dx.doi.org/10.4269/ ajtmh.2012.10-0558 PMid:22232460 PMCid:PMC3247118

12. Malik AN, John L, Bruceson AD, Lockwood DN. Changing pattern of visceral leishmaniasis, United Kingdom, 1985-2004. Emerg Infect Dis. 2006;12(8):1257-9. http://dx.doi.org/10.3201/ eid1708.050486 PMid:16965709 PMCid:PMC3291201

13. Weitzel T, Mühlberger N, Jelinek T, Schunk M, Ehrhardt $\mathrm{S}$, Bogdan C, et al. Imported leishmaniasis in Germany 2001-2004: data of the SIMPID surveillance network. Eur J Clin Microbiol Infect Dis. 2005;24(7):471-6. http://dx.doi. org/10.1007/s10096-005-1363-1 PMid:15997368

14. Bart A, van Thiel PP, de Vries HJ, Hodiamont CJ, Van Goo T. Imported leishmaniasis in the Netherlands from 2005 to 2012: epidemiology, diagnostic techniques and sequencebased species typing from 195 patients. Euro Surveill. 2013;18(30):pii=20544. Available from: http://www. eurosurveillance.org/ViewArticle.aspx?Articleld=20544

15. Varani S, Cagarelli R, Melchionda F, Attard L, Salvadori C, Finarelli AC, et al. Ongoing outbreak of visceral leishmaniasis in Bologna Province, Italy, November 2012 to May 2013. Euro Surveill. 2013;18(29): pii=20530. Available from: http://www. eurosurveillance.org/ViewArticle.aspx?Articleld $=20530$

16. Faber WR, Hoekzema R, Bart A, Zeegelaar JE, de Vries HJ. Cutaneous leishmaniasis acquired in Jura, France. Emerg Infect Dis. 2012;18(1):183-4. http://dx.doi.org/10.3201/ eid1801.110408 PMid:22257720 PMCid:PMC3310094

17. Gradoni L, Soteriadou K, Louzir H, Dakkak A, Toz SO, Jaffe C, et al. Drug regimens for visceral leishmaniasis in Mediterranean countries. Trop Med Int Health. 2008;13(10):1272-6. http:// dx.doi.org/10.1111/j.1365-3156.2008.02144.x PMid:18764817

18. Van der Auwera G, Maes I, De Doncker S, Ravel C, Cnops L, Van Esbroeck M, Van Gompel A, Clerinx J, Dujardin JC. Heatshock protein 70 gene sequencing for Leishmania species typing in European tropical infectious disease clinics. Euro Surveill. 2013;18(30):pii=20543. Available from: http://www. eurosurveillance.org/ViewArticle.aspx?Articleld=20543

19. Chicharro C, Llanes-Acevedo IP, García E, Nieto J, Moreno J, Cruz I. Molecular typing of Leishmania infantum isolates from a leishmaniasis outbreak in Madrid, Spain, 2009 to 2012. Euro Surveill. 2013;18(30):pii=20545. Available from: http://www. eurosurveillance.org/ViewArticle.aspx?Articleld=20545

20. Ruiz-Fons F, Ferroglio E, Gortázar C. Leishmania infantum in free-ranging hares, Spain, 2004-2010. Euro Surveill. 2013;18(30): pii=20541. Available from: http://www. eurosurveillance.org/ViewArticle.aspx?Articleld=20541

21. Arce A, Estirado A, Ordobas M, Sevilla S, García N, Moratilla L, de la Fuente S, Martínez AM, Pérez AM, Aránguez E, Iriso A Sevillano 0, Bernal J, Vilas F. Re-emergence of leishmaniasis in Spain: community outbreak in Madrid, Spain, 2009 to 2012 Euro Surveill. 2013;18(30):pii=20546. Available from: http:// www.eurosurveillance.org/ViewArticle.aspx?Articleld $=20546$ 